lesion acts as a detonator and discharges collateral stable cells situated in the highest motor centres (Hughlings Jackson) or pre-frontal lobes, we have a true epileptic fit differing from the one caused by a pre-frontal lesion, in that the motor symptoms commence on the opposite side of the body in the former and on the same side as the lesion in the latter. Is there any symptom which would aid us in distinguishing these two kinds of fits? Do the head and eyes undergo conjugate deviation away from the side of the lesion and of the initial spasm, and in this way differ from a fit due to a lesion in the Rolandic area, when the head and ey es deviate towards the side primarily convulsed ? The difference in intensity of optic neuritis, if present in both eyes, does not appear to be yet of any certain localising value. I hope some expert neurologist will kindly throw some light on the points I have raised, for al though the pre-frontal region is not experimentally excitable, there seems to be every reason to believe that a lesion of this region may give rise to a "physiological fulminate" or an "epileptogenous focus," the motor symptoms first showing themselves on the same side as the lesion.

I am, Sirs, y ours truly,

Alresford, Hants, Oct. 26th, 1891.

F. W. JOLLYE.

\section{THE USE OF ANTISEPTICS.}

\section{To the Editors of THE LANCET.}

SIRS,-In reference to the recent letters on the "Use of Antiseptics," would you kindly insert a few remarks which may tend to show that the views of the modern anti septarian and those of the disciple of "scrupulous cleanliness" are really not so diametrically opposed as the enthusiastic representative of either side might at first lead one to believe? Glancing at a list of our so-called antiseptics, it will at once be seen that their activity and efficiency increase directly with their known detrimental effect over the healthy reaction of the living tissues. A recognition of this injurious influence was doubtless what led to the antiseptic spray being originally condemned as deleterious by Mr. Lawson Tait and Dr. Bantock, and its final aboli. tion by the inventor himself. Now the modern anti septarian does not profess to see in antiseptics any peculiar intrinsic virtue, being fully aware of their injurious effect on the vitality of the tissues, as well as their germicidal power. He tries to avail himself of the latter property with the least possible sacrifice to the former; he uses them intelligently as a means to achieve an end, that end being asepticity. Further, it is obvious that in the intelligent use of antiseptics we have the readiest means of rendering our hands and instruments approximately aseptic during surgical manipulations; but as to the direct application of powerful germicides to $a b-$ sorbent surfaces, which formerly was much in vogue, from what I have above stated it follows that such a practice would be extremely injudicious, quite opposed to modern teaching, and would by lowering the vitality of the tissues render them more susceptible to the entrance and grow th of septic or pathogenic micro-organisms. Doubtless this too diligent use, or rather abuse, of antiseptics has in a great measure to account for the sweeping assertions recently put forward respecting their applicability, and led up to their condemnation and abolition in some quarters. Thus, although the reckless and meaningless use of such potent agents must be deprecated, still care must be taken lest the pendulum in swinging to rest may go too far in the opposite extreme, affording us an illustration (unfortunately not the first one in surgical literature) of the old proverb, "Ab Scylla in Charybdim." Now, the modern antiseptarian is far from being opposed to scrupulous cleanliness ; in it he recognises an approximation to his ideal asepticity, and only differs from the advocates of the former in the fact that he believes this much desired condition more readily attainable through the regulated use of antiseptics. Thus, on analysis, the broad principles underlying the actions of both are found to be identically the "same, a slight divergence being caused merely by the means adopted to secure the end ; and possibly with the discovery of a reliable nondecomposable and non-poisonous antiseptic, a desideratum still keenly felt, the distinction between the advocate of "scrupulous cleanliness" and the modern antiseptarian may cease to exist.

I am, Sirs, yours faithfully,

GaIway, Oct. 17th, $1891 . \quad$ Louis C. Bunton, M.B.

\section{BIRMINGHAM.}

(FROM OUR OWN CORRESPONDENT.)

Midland Medical Socicty.

THE annual meeting of this Society was held in the Medical Institute on the 1Ith inst., under the presidency of Mr. Bennett May. The address was given by Dr. James Little of Dublin, on the Resources of the Physician in the Management of Chronic Disease of the Heart. A large and appreciative andience listened to an extremely able and practical discourse, in which the experience of the lecturer was given. A vote of thanks, moved by Sir Walter Foster, and seconded by Dr. A. S. Underhill, was cordially carried. A new departure was made in the Society's proceedings this year, there being no supper following the address as heretofore, and the meeting therefore being held at the Medical Institute instead of at an hotel, a change which appeared to meet with the approval of the members, judging from the numbers present.

Margarine as Butter.

A tradesman was lately fined $40 \mathrm{~s}$. and costs for selling margarine as butter. This common practice will probably receive a useful check by this fine, but the infliction of a fine only does not appear to diminish the number of cases which crop up in this direction. It is much like the smoke nuisances which so constantly arise, and where a small fine now and again is taken no notice of by manufacturers, who exhibit no interest in the matter, and certainly adopt no steps to abate it.

\section{Orthopadic and Spinal Hospital.}

The annual meeting of this charity was held on the 6th inst. The Marquis of Hertford presided. The report showed that the expenditure for the year was $£ 15559 \mathrm{~s}$. $3 d$, and the income $f 1359 \mathrm{l} s$. 3d., leaving a deficiency of $£ 1968 s$. There were cases still waiting to be admitted : some had been waiting for months, showing the want of increased accommodation. An intimation was given of a legacy by the late Mr. Avins, which will probably amount to $£ 22,000$, the receipt of which in due time will materially add to the prosperity of the hospital, which is now doing a great and valuable amount of good among the poorer classes of the city and surrounding district.

\section{Centralisation of Hospital Administration.}

Attention has been called to this subject by a letter in the Birmingham Daily Gazette, and a proposal is made to centralise and consolidate our local medical institutions. It is pointed out that there are two general and six special hospitals in the city, the work of which overlaps that of the others to a greater or less extent. The advantages referred to are: (1) finance and administrative economy ; (2) uniformity of management; (3) greater facility and effective. ness in the introduction of measures of reform; (4) im. provement in the status of the smaller hospitals; (5) simplification and greatly increased efficiency of the arrangements for education of medical students. At the least, it is suggested, for the sake of the Medical School, that the General and Queen's Hospitals should be amalgamated. The latter suggestion bears the impress of practicability, and no doubt would result in considerable advantage to all concerned. The former part of the plan appears, from the present standpoint, impossible of accomplishment; but as a dream of the future it is worthy of reflection and ultimate elaboration. Whether it will be met by the vigour and determination necessary to its realisation remains to be seen. Our public men at this time are too much absorbed in work to battle with the gigantic development which would accompany the details of such a scheme.

Birmingham, Nov. 12th.

\section{NORTHERN COUNTIES NOTES.}

\section{(FroM OUR OWN CORRESPONDENT.)}

\section{Newcastle.}

THE chief constable of Newcastle, Captain Nicholls, in his annual report, accounts for the large increase of cases of drunkenness by the prosperous condition of the working classes in this very populous district, of which Newcastle is the principal market. He remarks that the only district in 